\title{
Infektivitas parasit Ichtyophthirius multifiliis yang disimpan pada suhu rendah
}

\section{The infectivity of Ichtyophthirius multifiliis against low temperature storage}

\author{
Rahman*, Sukenda, Sri Nuryati, Dendi Hidayatullah \\ Departemen Budidaya Perairan, Fakultas Perikanan dan Ilmu Kelautan, Institut Pertanian Bogor \\ Kampus IPB Dramaga Bogor, Jawa Barat 16680 \\ *Surel: rahmanaquaculture@ipb.ac.id
}

\begin{abstract}
The aim of this study was to evaluate infectivity of Ichtyophthirius multifiliis which caused white spot disease maintained at low temperature without its host. Briefly, the trophont stage of parasites were subjected at control $\left(28^{\circ} \mathrm{C}\right)$ and lower temperature $\left(9^{\circ} \mathrm{C}\right)$ for 14 consecutive days of observation. The rate of survival, and excystment of descendants were examined descriptively at the last day of observation. Here, the infectivity of parasite then performed by means infecting the model fish Poecilia sphenops (black moly) with escaping theronts. The results revealed that the survival rate and excystment rate of parasite were decreased as maintaining period increased. The final rate of survival, and excystment of parasite were 35\% and 33,3\% respectively. Additionally, the descendants came out with high abnormality which recognized by weak mobility and lower infectivity (50\%) compared to the control (80\%). Then, it is concluded that, maintaining I. multifiliis at low temperature without its host for 14 consecutive days will decreased the infectivity.
\end{abstract}

Keywords: white spot, obligat parasite, excystment, infectivity

\begin{abstract}
ABSTRAK
Penelitian ini bertujuan untuk mengevaluasi infektivitas parasit Ichtyophthirius multifiliis penyebab penyakit bintik putih (white spot) yang dipelihara tanpa inang pada suhu rendah. Parasit dengan stadia trophont dipelihara pada suhu ruang $\left(28^{\circ} \mathrm{C}\right)$ dan suhu rendah $\left(9^{\circ} \mathrm{C}\right)$ selama 14 hari. Selama masa pemeliharaan tersebut tingkat kelulusan hidup, dan tingkat eksismen parasit diukur dan dibandingkan secara deskriptif. Hari terakhir pemeliharaan dilakukan uji tantang pada ikan black moly Poecilia sphenops untuk menilai infektivitas parasit. Hasil penelitian memperlihatkan bahwa tingkat kelulusan hidup dan eksismen parasit semakin menurun dengan bertambahnya masa pemeliharaan. Akhir pengamatan kelangsungan hidup, dan nilai eksismen tersebut berturut-turut adalah $35 \%$ dan 33\%. Parasit yang disimpan pada suhu rendah selama 14 hari memperlihatkan infektivitas yang lebih rendah (50\%) dibandingkan dengan perlakuan kontrol (80\%). Kesimpulannya, penyimpanan parasit I. multifiliis pada suhu rendah selama 14 hari dapat menurunkan infektivitas parasit pada inang.
\end{abstract}

Kata kunci: bintik putih, parasit obligat, eksismen, infektivitas

\section{PENDAHULUAN}

Parasit Ichthyophthirius multifiliis adalah organisme Ciliata yang menyerang epidermis ikan dan menimbulkan bintik putih (white spot) pada sekujur tubuh ikan (Farmer et al., 2013; Zhang et al., 2103; von Gersdorff Jørgensen, 2016). Wabah white spot menyebabkan kerugian yang signifikan bagi industri akuakultur (Wei et al., 2013; Olsen et al., 2011, Xu et al., 2016). Selain dapat berperan sebagai agen infeksi primer, parasit ini dapat juga membawa agen infeksius sekunder (Xu et al., 2012b; Xu et al., 2013). Hal tersebut menjadikan parasit ini telah menjadi objek penelitian lebih dari 100 tahun (Dickerson \& Findly, 2014) terkait perubahan patofisiologi (Abdel-Hafez et al., 2014), pengobatan (Song et al., 2015; Shan et al., 2014; Kawano \& Hirazawa, 2012; Yao et al., 2011), dan respons imunitas (Xu et al., 2014; Zhao et al., 2013; Xu \& Klesius, 2013; ) pada inang. Adanya sifat obligat inang dari parasit I. multifiliis dan laju peralihan 
stadia yang tinggi mengakibatkan propagasi parasit selama ini dilakukan secara in vivo. Hal ini membatasi perbanyakan parasit pada skala laboratorium, karena membutuhkan banyak ikan hidup untuk multiplikasi dan koleksinya (Nielsen \& Buchmann, 2000).

Usaha memisahkan dari inangnya dan mengembangbiakannya secara in vitro telah dilakukan oleh beberapa peneliti namun masih belum memberikan hasil yang memuaskan. Oleh karena itu untuk saat ini pemeliharaan secara in vitro lebih ditujukan untuk memperpanjang masa simpan parasit (Dan et al., 2009). Meskipun tingkat patogenisitas I. multifiliis juga ditentukan oleh faktor lain seperti $\mathrm{pH}$ dan kesadahan air budidaya saat infeksi terjadi (Garcia et al., 2011), namun perlakuan saat penyimpanan parasit diduga juga memiliki pengaruh terhadap patogensisitas parasit. Penelitian lanjut untuk mengungkap bagaimana pemeliharaan secara in vitro berpengaruh pada kualitas parasit sangatlah diperlukan. Penelitian ini bertujuan untuk mengevaluasi infektivitas parasit I. multifiliis penyebab penyakit bintik putih yang dipelihara tanpa inang pada suhu rendah.

\section{BAHAN DAN METODE}

Ektoparasit yang digunakan adalah stadia trophont yang diperoleh dari ikan yang terinfeksi oleh parasit I. multifiliis. Sampel ikan dibawa ke laboratorium kesehatan organisme akuatik, Departemen Budidaya Perairan, Institut Pertanian Bogor untuk diisolasi. Ikan ditempatkan pada wadah bervolume $1 \mathrm{~L}$. Kemudian parasit yang melepaskan diri dari ikan dikumpulkan pada cawan petri yang berisi air kolam yang steril. Parasit yang terkumpul dibilas beberapa kali untuk menghilangkan debris dan kotoran.

Sel trophont dengan ukuran minimal 350 $\mu \mathrm{m}$ dipilih dan dikumpulkan ke dalam 20 tabung reaksi berisi air kolam steril $10 \mathrm{~mL}$ dan bersuhu $10{ }^{\circ} \mathrm{C}$ untuk mencegah terjadinya kista. Kepadatan sel parasit yang digunakan adalah 20 sel/tabung. Selanjutnya 17 tabung akan disimpan pada suhu rendah $\left(9 \pm 2{ }^{\circ} \mathrm{C}\right)$ di dalam refrigerator selama 14 hari, sedangkan sisanya tiga tabung sebagai kontrol disimpan pada suhu ruang. Pengamatan dilakukan selama 14 hari dengan cara menuangkan tabung pada cawan petri untuk diamati di bawah mikroskop perbesaran 100 kali dan diukur parameternya. Parameter yang diamati adalah persentase kelangsungan hidup, persentase sel tomont yang melepaskan theront (eksismen), abnormalitas, dan infektivitas parasit. Setelah itu sel dipulihkan dengan menginkubasi sel pada suhu $28 \pm 1^{\circ} \mathrm{C}$ selama 12 jam dan kembali diukur parameter pengamatannya (Dan et al., 2006). Data yang didapatkan selanjutnya dianalisis secara deskriptif.

Uji infektivitas parasit setelah pemeliharaan pada suhu rendah dilakukan dengan cara memulihkan trophont pada suhu $28{ }^{\circ} \mathrm{C}$ agar menghasilkan theront. Sel theront yang dihasilkan selanjutnya dikumpulkan dan dipelihara bersama sepuluh ekor ikan black moly $(1,5 \pm 0,5 \mathrm{~g})$. Infeksi dilakukan dalam akuarium dengan ruang yang diatur pada suhu $23-24{ }^{\circ} \mathrm{C}$ selama 14 hari. Parasit dianggap infektif jika menimbulkan gejala bintik putih pada ikan. Infektivitas parasit digambarkan dengan nilai prevalensi yang merupakan persentase ikan yang terinfeksi dari populasi yang diamati. Abnormalitas sel theront diamati berdasarkan adanya kelainan tingkah laku sel, variasi ukuran, dan mobilitas sel.

\section{HASIL DAN PEMBAHASAN}

Sel trophont yang berasal dari suhu ruang cenderung untuk berenang ke dasar petri dish dan menempel. Proses diawali dengan mengeluarkan material lengket untuk menempel dan dalam beberapa menit mulai membentuk kista. Proses pembentukan kista dimulai dari jam ke-19 yang terjadi secara perlahan dan berakhir pada jam ke-26. Hal demikian juga terjadi pada sel yang berasal dari penyimpanan suhu rendah namun membutuhkan waktu yang lebih lama. Kista dari penyimpanan suhu rendah terbentuk pada semua sel throphont pada jam ke-72 tanpa dengan adanya material lengket. Setiap pengkondisian sel parasit pada suhu pemulihan (suhu ruang) berhasil merangsang sel untuk kembali memulai eksismen dengan nilai yang semakin rendah. Hasil pengukuran disajikan pada Tabel. 1.

Seluruh sel trophont yang dipelihara pada suhu rendah mampu bertahan selama enam hari, selanjutnya tingkat kehidupan sel trophont mengalami penurunan secara gradual hingga tersisa 35\% parasit pada hari terakhir pengamatan. Sel parasit yang mati selama penyimpanan pada suhu rendah tidak mengalami lisis sehingga mudah diamati di bawah mikroskop. Kematian sel dicirikan dengan tidak adanya pergerakan sel maupun pergerakan silia. Perlakuan kontrol terlihat sel parasit beralih stadia dalam 26 jam, sehingga pada hari selanjutnya tidak ditemukan lagi parasit dalam stadia trophont maupun tomont. 
Tabel 1. Parameter uji selama penelitian

\begin{tabular}{|c|c|c|c|c|c|c|c|}
\hline \multirow{3}{*}{ Hari } & \multicolumn{2}{|c|}{ SR $(\%)$} & \multicolumn{3}{|c|}{ Persentase eksismen $(\%)$} & \multicolumn{2}{|c|}{ Abnormalitas } \\
\hline & \multirow{2}{*}{ Kontrol } & \multirow{2}{*}{ Perlakuan } & \multirow{2}{*}{ Kontrol } & \multicolumn{2}{|c|}{ Suhu rendah } & \multirow{2}{*}{ Kontrol } & \multirow{2}{*}{ Suhu rendah } \\
\hline & & & & $9 \pm 2{ }^{\circ} \mathrm{C}$ & Pemulihan & & \\
\hline 0 & 100 & 100 & 100 & 0 & 100 & - & - \\
\hline 1 & 100 & 100 & 100 & 0 & 100 & - & - \\
\hline 2 & - & 100 & - & 0 & 100 & - & - \\
\hline 3 & - & 100 & - & 0 & 100 & - & - \\
\hline 4 & - & 100 & - & 0 & 100 & - & + \\
\hline 5 & - & 100 & - & 0 & 100 & - & + \\
\hline 6 & - & 100 & - & 0 & 100 & - & + \\
\hline 7 & - & 92 & - & 0 & 66 & - & ++ \\
\hline 8 & - & 85 & - & 0 & 66 & - & ++ \\
\hline 9 & - & 80 & - & 0 & 66 & - & +++ \\
\hline 10 & - & 77 & - & 0 & 66 & - & +++ \\
\hline 11 & - & 68 & - & 0 & 66 & - & +++ \\
\hline 12 & - & 48 & - & 0 & 33 & - & +++ \\
\hline 13 & - & 40 & - & 0 & 33 & - & +++ \\
\hline 14 & - & 35 & - & 0 & 33 & - & +++ \\
\hline
\end{tabular}

Keterangan: $+++=$ sangat banyak; $++=$ banyak; $+=$ sedikit.

Terdapat hubungan yang lurus antara ukuran sel trophont dan viabilitasnya setelah terlepas dari inang (Dickerson, 2006). Dalam penelitian ini, hanya sel berukuran minimal $600 \mu \mathrm{m}$ yang bertahan hidup yang mungkin terkait dengan ketersediaan cadangan makanan selama pemeliharaan suhu rendah. Cadangan lipid dan kista sangat menentukan kelangsungan hidup parasit saat lepas dari inang (Ewing \& Kocan, 1986). Proses penyimpanan pada suhu rendah memperlambat pembentukan kista, yang ditandai dengan tidak terbentuknya material lengket. Perlambatan ini hanya menginterupsi proses pembentukan kista secara temporer dan selanjutnya jumlah sel tomont yang teramati jumlahnya semakin meningkat setelah hari kedua.

Gejala lain yang menarik adalah menurunnya kemampuan beberapa sel tomont melepaskan tomite dengan bertambahnya masa pemeliharaan. Tomite tidak seluruhnya dapat lepas dari kista dan terbentuk dengan membutuhkan waktu selama 36 jam, jauh lebih lama dari perlakuan kontrol yang hanya memakan waktu 20 hingga 24 jam. Gejala tersebut diikuti dengan semakin meningkatnya abnormalitas yang teramati pada sel anakan (Gambar 1). Abnormalitas parasit yang teramati antara lain mobilitas sel yang rendah, dan ukuran sel tomite yang tidak seragam. Penelitian sebelumnya yang telah dilakukan oleh Dan et al, (2009) pada parasit Cryptocaryon irritans juga menemukan gejala yang sama.

Kemampuan parasit yang dipelihara pada suhu rendah dalam menimbulkan gejala white spot pada ikan black molly memperlihatkan nilai yang lebih rendah dibandingkan dengan parasit kontrol seperti yang teramati pada Gambar 2. Penurunan kemampuan menginfeksi parasit diduga terkait dengan tingginya abnormalitas sel parasit yang dihasilkan. Sel tomite yang dihasilkan dari parasit yang dipelihara pada suhu rendah cenderung beragam ukurannya, rendah mobilitas, dan hanya berenang berputar-putar di dalam sel tomont. Abnormalitas sel tomite selanjutnya akan meningkatkan abnormalitas pada sel theront, terutama pada mobilitas sel dalam mencari inang.

Jika pada kondisi mobilitas sel normal hanya $50 \%$ sel theront yang berpeluang mendapatkan inang (Ewing et al., 1986), maka peluang tersebut diduga akan lebih rendah pada sel abnormal dengan mobilitas sel yang lemah, yang akan menekan infektivitas parasit dan terlihat dengan rendahnya nilai prevalensi.

Berdasarkan pengamatan selama dilakukan uji infektivitas, ikan memperlihatkan perubahan 

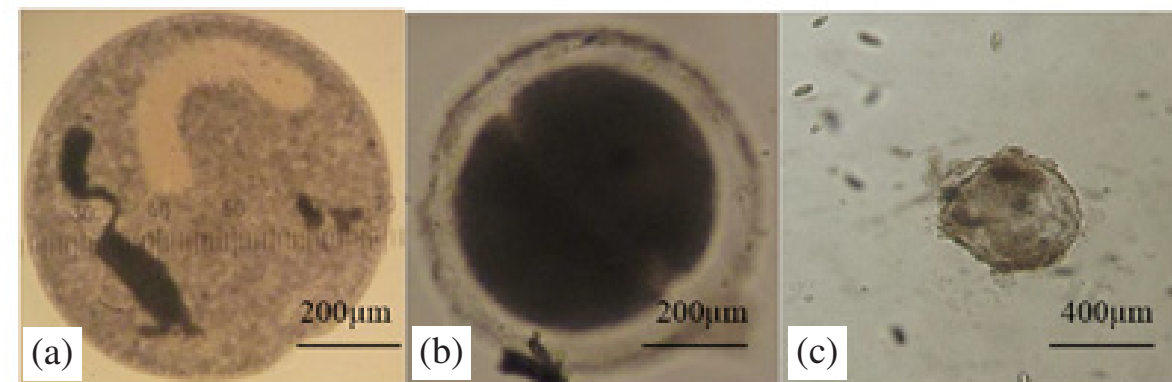

(d)

Gambar 1. (a) Stadia trophont pada hari pertama, (b) proses enkistmen ditandai dengan pembentukan kista dan inisiasi pembelahan sel, (c) proses eksismen yang ditandai lepasnya sel anakan dari kista, (d) beberapa sel tomite yang berhasil terbentuk dengan sempurna pada hari ke-14 tetapi gagal keluar dari kista.

tingkah laku pada hari ketiga pascainfeksi yaitu beberapa ikan terlihat pasif di dasar akuarium. Produksi mukus yang berlebih terlihat pada hari kelima pascainfeksi, dan selanjutnya pada hari ketujuh mulai muncul bintik putih pada beberapa ikan uji (Gambar 3). Jumlah ikan dengan gejala bintik putih jumlahnya semakin bertambah hingga hari ke-14. Gejala tersebut teramati dengan jelas pada ikan yang diinfeksi dengan sel theront baik dari penyimpanan suhu kontrol maupun suhu rendah.

Parasit ditemui pada semua permukaan tubuh luar ikan, namun pada bagian insang ditempeli parasit dengan jumlah individu yang lebih banyak dibandingkan bagian tubuh lainnya. Hal ini kemungkinan terkait dengan adanya preferensi parasit dalam memilih lokasi penempelan pada tubuh luar inang. Sitjà-Bobadilla (2008) menduga insang menjadi preferensi parasit I. multifiliis dikarenakan lapisan mukus pada insang lebih tipis untuk memungkinkan pertukaran gas yang secara tidak langsung mengakibatkan proteksi imunitas pada insang juga lebih rendah. Kematian ikan pada ikan yang terinfeksi teramati pertama kali pada hari kedelapan dan semakin meningkat pada hari ke-14 pascainfeksi. Mekanisme kematian ikan diduga akibat beberapa hal seperti kerusakan sistem osmoregulasi dan sistim respirasi, serta keracunan amonia akibat rusaknya insang ikan (Xu et al., 2012a). Selain itu, kondisi stress akibat infeksi dapat memicu penigkatan kortisol pada ikan yang pengaruhnya menekan fungsi sistem imunitas ikan (Davis et al., 2003).

\section{KESIMPULAN}

Berdasarkan penelitian yang dilakukan, penyimpanan parasit Ichtyophthirius multifiliis tanpa inang pada suhu rendah dalam waktu yang singkat (14 hari) dapat menurunkan kemampuan infektivitas sel theront yang dihasilkan.

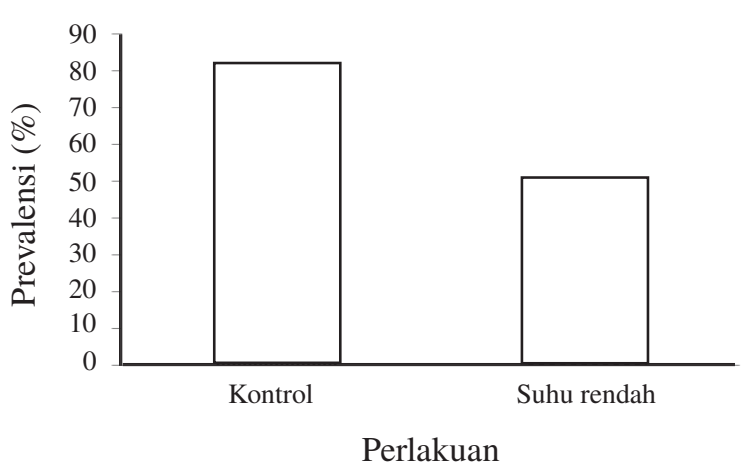

Gambar 2. Uji infektivitas parasit Ichthyophthirius multifiliis pada ikan black moly perlakuan suhu rendah dan suhu normal. Nilai prevalensi didapatkan setelah pengamatan gejala klinis selama 14 hari pasca infeksi.

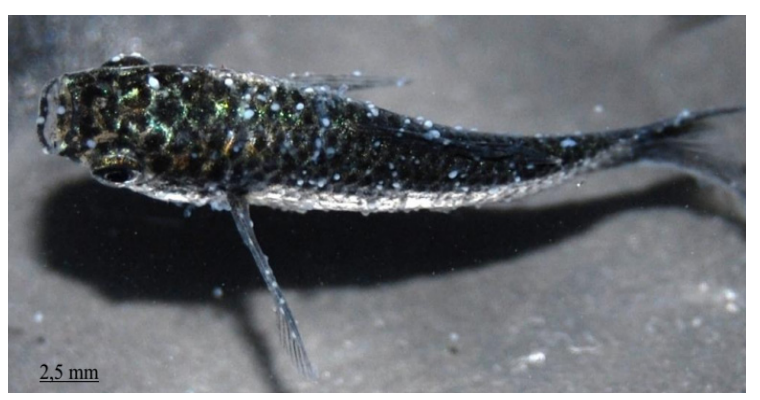

Gambar 3. Ikan black moly Poecilia sphenops yang terinfeksi Ichtyophthirius multifiliis pada uji infektivitas. Titik putih pada tubuh adalah parasit yang telah berkembang menjadi stadia trophont.

\section{DAFTAR PUSTAKA}

Abdel-Hafez G, Lahnsteiner F, Mansour N, Licek E. 2014. Pathophysiology of Ichthyophthirius multifiliis infection in rainbow trout Oncorhynchus mykiss and chub Leuciscus cephalus. Journal of comparative pathology 151: 394-399.

Dan XM, Li AX, Lin XT, Teng N, Zhu XQ. 2006. A standardized method to propagate Cryptocaryon irritans on a susceptible host 
pompano Trachinotus ovatus. Aquaculture 258: 127-133.

Dan XM, Lin XT, Yan YX, Teng N, Tan ZL, Li AX. 2009. A technique for the preservation of Cryptocaryon irritans at low temperatures. Aquaculture 297: 112-115.

Davis KB, Griffin BR, Gray WL. 2003. Effect of dietary cortisol on resistance of Channel catfish to infection by Ichthyopthirius multifiliis and Channel catfish virus disease. Aquaculture 218: 121-130.

Dickerson HW. 2006. Ichthyopthirius multifiliis and Cryptocaryon irritans (phylum Ciliophora). In: PTK Woo (ed). Fish Diseases and Disorder. London, UK: Protozoan and Metazoan Infection. $2^{\text {nd }}$ Edition. Hlm. 117146.

Dickerson HW, Findly RC. 2014. Immunity to Ichthyophthirius infections in fish: A synopsis. Developmental and Comparative Immunology 43: 290-299.

Ewing MS, Kocan KM. 1986. Ichthyopthirius multifiliis (Ciliophora) development in gill epithelium. Journal of Eukaryotic Microbiology 33: 369-374

Ewing MS, Lynn ME, Ewing SA. 1986. Critical periods in development of Ichthyophthirius multifiliis (Ciliophora) populations. The Journal of Protozoology 33: 388-391.

Farmer BD, Fuller SA, Mitchell AJ, Straus DL, Bullard SA. 2013. Efficacy of bath treatments of formalin and copper sulfate on cultured white bass Morone chrysops concurrently infected by Onchocleidus mimus and Ichthyophthirius multifiliis. Journal of the World Aquaculture Society 44: 305-310.

Garcia LDO, Becker AG, Cunha MA, Baldisserotto B, Copatti CE, Kochhann D. 2011. Effects of water $\mathrm{pH}$ and hardness on infection of silver catfish Rhamdia quelen fingerlings by Ichthyophthirius multifilis. Journal of the World Aquaculture Society 42: 399-405.

Kawano F, Hirazawa N. 2012. Antiparasitic effect of in-feed inhibitors of folic acid synthesis and dihydrofolate reductase against ciliate Cryptocaryon irritans infection in the red sea bream Pagrus major and against ciliate Ichthyophthirius multifiliis infection in black pop-eyed goldfish Carassius auratus. Aquaculture 330: 1-7.

Nielsen CV, Buchmann K. 2000. Prolonged in vitro cultivation of Ichthyophthirius multifilis using an EPC cell line as substrate. Diseases of Aquatic Organisms 42: 215-219.

Olsen MM, Kania PW, Heinecke RD, Skjoedt K, Rasmussen KJ, Buchmann K. 2011. Cellular and humoral factors involved in the response of rainbow trout gills to Ichthyophthirius multifiliis infections: molecular and immunohistochemical studies. Fish and Shellfish Immunology 30: 859-869.

Shan XF, Kang YH, Bian Y, Gao YH, Wang WL, Qian AD. 2014. Isolation of active compounds from methanol extracts of Toddalia asiatica against Ichthyophthirius multifiliis in goldfish Carassius auratus. Veterinary Parasitology 199: 250-254.

Song K, Ling F, Huang A, Dong W, Liu G, Jiang C, Zhang Q, Wang G. 2015. In vitro and in vivo assessment of the effect of antiprotozoal compounds isolated from Psoralea corylifolia against Ichthyophthirius multifiliis in fish. International Journal for Parasitology Drugs and Drug Resistance 5: 58-64.

Sitjà-Bobadilla A. 2008. Living off a fish: a tradeoff between parasites and the immune system. Fish and Shellfish Immunology 25: 358-372.

von Gersdorff Jørgensen L. 2016. The dynamics of neutrophils in zebrafish Danio rerio during infection with the parasite Ichthyophthirius multifiliis. Fish and Shellfish Immunology 55: 159-164.

Wei JZ, Li H, Yu H. 2013. Ichthyophthiriasis: emphases on the epizootiology. Letters in Applied Microbiology 57: 91-101.

Xu DH, Shoemaker CA, LaFrentz BR. 2014. Enhanced susceptibility of hybrid tilapia to Flavobacterium columnare after parasitism by Ichthyophthirius multifiliis. Aquaculture 430: 44-49.

Xu DH, Klesius PH. 2013. Comparison of serum antibody responses and host protection against parasite Ichthyophthirius multifiliis between Channel catfish and Channel $\times$ blue hybrid catfish. Fish and Shellfish Immunology 34: $1.356-1.359$.

$\mathrm{Xu}$ DH, Shoemaker CA, Zhang Q, Klesius PH. 2013. Naturally infected Channel catfish Ictalurus punctatus concurrently transmit Ichthyophthirius multifilis and Edwardsiella ictaluri to naïve Channel catfish. Aquaculture 376: 133-136.

Xu, DH, Pridgeon JW, Klesius PH, Shoemaker CA. 2012a. Parasitism by protozoan Ichthyophthirius multifilis enhanced invasion of Aeromonas hydrophila in tissues of Channel catfish. Veterinary Parasitology 184: 101-107. 
Xu DH, Shoemaker CA, Klesius PH. 2012b. Ichthyophthirius multifiliis as a potential vector of Edwardsiella ictaluri in Channel catfish. FEMS Microbiology Letters 329: 160-167.

Xu DH, Zhang QZ, Shoemaker CA, Zhang D, Moreira GS. 2016. Molecular immune response of Channel catfish immunized with live theronts of Ichthyophthirius multifiliis. Fish and Shellfish Immunology 54: 86-92.

Yao JY, Zhou ZM, Li XL, Yin WL, Ru HS, Pan XY, Hao GJ, Shen JY. 2011. Antiparasitic efficacy of dihydrosanguinarine and dihydrochelerythrine from Macleaya microcarpa against Ichthyophthirius multifiliis in richadsin Squaliobarbus curriculus. Veterinary Parasitology 183: 8-13.

Zhang Q, Xu DH, Klesius PH. 2013. Evaluation of an antiparasitic compound extracted from Galla chinensis against fish parasite Ichthyophthirius multifiliis. Veterinary Parasitology 198: 45-53.

Zhao F, Li YW, Pan HJ, Shi CB, Luo XC, Li AX, Wu SQ. 2013. Expression profiles of toll-like receptors in Channel catfish Ictalurus punctatus after infection with Ichthyophthirius multifiliis. Fish and Shellfish Immunology: 35: 993-997. 